\title{
Ouyang Jingwu: Buddhism Is neither Religion nor Philosophy but What the Present Generation Is in Need of
}

(China 1922)

\section{Introduction}

The following piece marks the most famous and provocative attempt by Ouyang Jingwu (1870-1943), an influential Buddhist layman, to stem the tide of reinterpreting Buddhism along Western lines of reasoning. Instead, Ouyang argued for a self-conscious insistence on genuine Buddhist categories which he held to be not only superior but also the only adequate way to express Buddhism even in the modern age. By this, he meant to challenge not only general perceptions and ascriptions by non-Buddhists, but also the strategy of those Buddhist "modernizers" who in his eyes succumbed terminologically to alien concepts. His provocation would be taken up by the leading voice of those "modernizers," the monk Taixu (1890-1947), thus turning the whole affair into one of the most notable debates in early twentieth-century Chinese Buddhism on how to deal with the challenges of modernity.

The author, Ouyang Jian, courtesy name Jingwu, was born into a literati household in Jiangxi province. Although he at first followed the provisioned path of the civil service examinations, the early death of his father and elder brother and later of his beloved mother led him to question the answers his neo-Confucian upbringing held to the most fundamental problems in life. ${ }^{2}$ He therefore began turning to Buddhism. In 1904, Ouyang first had contact with Yang Wenhui, the "father of the Buddhist revival" in China and a layman, with whom he studied in Nanjing. On the latter's recommendation, he also briefly went to Japan where he met the well-known Chinese intellectuals Zhang Binglin and Liu Shipei, who were also at that time interested in Buddhism. Back in China, Ouyang took up a teaching position in Canton, but a severe illness, which he only barely survived, soon forced him into giving up his job. In 1910 he was back in Nanjing with Yang Wenhui, studying Buddhism, namely weishi (mere consciousness)-Buddhism, a

\footnotetext{
$1 \quad$ Taixu refuted Ouyang's views in various texts, including "Fofa shi fo zhexue" (Is Buddhism philosophy?) (1925) in Haichaoyin wenku (Text collection of the [journal] 'Sound of the sea tide'), 26 vols. (Taipei: Xinwenfeng 1985), vol. 19/1, 222-34; or "Wo zhi zongjiao guan" (My views on religion) (1925) in Haichaoyin wenku, vol. 2/1, 9-19.

$2 \quad$ See a letter by Ouyang cited in the biographical sketch by Zhou Bangdao and Zhang Douhang in Ouyang's collected works: Ouyang Dashi Yiji (Collection of writings left behind by master Ouyang), 4 vols. (Taipei: Xinwenfeng 1976), vol. 1, i-x.
} 
school largely forgotten in China after the Tang dynasty but at the time newly en vogue because of its perceived "modernity" and compatibility of its epistemological thrust with Western logical, scientific thinking. ${ }^{3}$ This school stood in the tradition of Buddhist logic and argued that all phenomena were mere emanations of consciousness. The latter was further differentiated into eight types of consciousness to explain origination and the process of cognition in a highly complex manner. This very intellectualist teaching would remain central to Ouyang's thinking, and when Yang Wenhui died in 1911, Ouyang took over the latter's Buddhist printing press and the adjunct educational centre, in the course of time establishing an "Institute for Inner Studies" (Neixueyuan) ${ }^{4}$ (1922) there to teach Buddhism to interested intellectuals. His lectures became famous for their quality, and noted Chinese intellectuals including Liang Qichao, Zhang Junmai, Li Shicen, Liang Shuming, Xiong Shili, and Tang Yongtong attended. Western observers, however, noted the rather aristocratic, elitist atmosphere and complained about the difficult, overly erudite teaching style. ${ }^{5}$

Ouyang focused not only on the weishi (Vijshi focused) school of the Yogācāra branch, but also covered other Indian traditions such as texts centering on Prajra (wisdom) and Nirvana. This emphasis on the Indian (in contrast to "sinified") traditions made the famous Bengali poet Rabindranath Tagore remark that Ouyang appeared to him as an incarnation of the long-lost Indian soul. ${ }^{6}$ Ouyang insisted on a systematic approach and on sharp distinctions, refuting the alternative approach mainly embodied by his one-time class-mate at Yang Wenhui's, the reformer monk Taixu, who aimed at a Buddhist reform via integrationalist means. This "conciliatory" attitude, which tried to integrate all of received Buddhist tradition (and even of non-Buddhist thinking) in the traditional model of a hierarchy of teachings (panjiao), was to Ouyang's mind a mere hodgepodge, an intellectual selling-out of truth claims, gave up made accessible the texts long vanished in China. Japanese Buddhism and Buddhology at the turn of the century was heavily influenced by Western philology (e.g. Sanskrit studies) and the nineteenth-century "back to the roots" movement associated with Max Müller in Oxford, with whom early Japanese Buddhologists had studied. The equation of authenticity and antiquity brought early Buddhism and thus "Hīnayāna" back to appreciation. Müller's East Asian students, Buddhists themselves, were surprised, and there even rose a movement to relaunch Buddhism in India, mainly pushed by the Sri Lankan Anagarika Dharmapala. This context suggests that Mahāyāna as a later development in Buddhism was liable to the charge of "forgery" or "aberration." One of the consequences was a new interest in the Indian foundations of Buddhism, another the quest for inner-Buddhist criteria for authenticity which could bolster Mahāyāna against "forgery" charges, since "Hīnayāna" was never seen as a real alternative to draw on in East Asia. The fact that Ouyang favoured weishi thus has to be seen in a broader context, even though he himself did not express this directly but rather put forward mainly dogmatic considerations.

4 The term "inner studies" was used to distinguish the teaching from all "outer" ways, e.g. Indian non-Buddhist teachings or Confucianism and Daoism. Ouyang defined "inner" as "untainted" and "unmitigated experience." The translation sometimes given in Western literature as "Metaphysical Institute" is not pertinent to Ouyang's intentions and therefore not used here.

$5 \quad$ See Karl Reichelt, Truth and Tradition in Chinese Buddhism (Shanghai: The Commercial Press, 1927), 303; James Pratt, The Pilgrimage of Buddhism (New York: Macmillan, 1928), 387-88.

$6 \quad$ See Zhou/Zhang, Ouyang Dash Yiji, ix. 
standards of judgement, and was logically inconsistent from the start. Therefore, he not only insisted on inner-Buddhist distinctions, e.g. rejecting long-accepted "apocrypha," but also launched the provocative lecture "Buddhism is neither religion nor philosophy but what the present generation is in need of" (1922) to claim Buddhism's total alterity. ${ }^{7}$ Ouyang mainly held lectures and wrote prefaces to canonical writings (in itself already suggesting that he did not see himself as a "philosopher" but rather as an exegete). Since both "philosophy" and "religion" are Western terms, his argumentation is of obvious relevance to the question of confronting Buddhism with Western thought, but the second part of the lecture has to be considered as well as it reveals Ouyang's attitude toward the times he lived in. In the end, although Ouyang meant to oppose the self-styled "reformers," his own version of Buddhism was not "traditional" either, but in itself just another way of reacting to the changed circumstances.

With his famous dictum "Buddhism is neither religion nor philosophy," Ouyang provocatively took up the problem of defining Buddhist identity in an increasingly complex intellectual surrounding. His term for "Buddhismo," fofa, literally "buddha dharma," decidedly rejected other terms like the common fojiao ("buddhist teaching"), since this went hand in hand with other jiao (teachings) and was part of zongjiao, the Chinese term for Western "religion," taken over from Japanese. ${ }^{8}$ With this accent on fa or dharma, Ouyang expressed a claim to universality which a jiao could not pose. $F a$, in Chinese also meaning law, in this sense and context could not be plural: it implied the law governing the universe, whereas there could be many jiao. Therefore Ouyang insisted on the inapplicability of "religion" and "philosophy" to Buddhism.

Ouyang's primary argument against a terminological compatibility between the Western categories of "religion" and "philosophy" rests on the premise that Buddhism as buddha dharma is per definition absolute and all-comprising. Thus, the problem of Western categories versus Buddhism is framed in a "parts and whole" relationship. Still, Ouyang does not limit himself to the formal level, but goes on to show that the nature of "religion" and "philosophy" is also incomparable to Buddhism. In this context, he gives definitions of "religion" and of "philosophy" - as if these were uncontested - to demonstrate that Buddhism does not meet either of these definitions and thus cannot be considered a member of these categories.

\footnotetext{
$7 \quad$ Ouyang announced the complete lecture but actually gave only the first part ("Buddhism is neither religion nor philosophy"), addressing it to an educational philosophical study association. Consequently, he printed only this first part in his own collection of writings (Ouyang Jingwu xiansheng neiwaixue, Inner and outer teachings of Mr. Ouyang Jingwu, Nanjing: Jinling kejingchu n.d.), whereas the second ("Buddhism is what the present generation is in need of") was completed by his follower Wang Enyang, who had also written down the first part, but in this case without being proof-read by Ouyang. The whole piece appears in the collection of Ouyang's writings assembled after his death: Ouyang dashi Yiji, 3457-3482. The whole lecture had also appeared in the non-Buddhist intellectual journal Minduo (People's bell), vol. 3, no. 3, in March 1922.

8 Federico Masini, "The Formation of Modern Chinese Lexicon and Its Evolution, Toward a National Language: The Period from 1840 to 1898," Journal of Chinese Linguistics 6 (Berkeley: University of California, 1993), 100; $101 ; 222$.
} 
Ouyang's aim in these definitions is obvious. Both religion and philosophy are partial because they are one-sided: religion stresses pure deduction and faith, enslaving the believer, philosophy stresses pure induction and conventional reasoning, but leads nowhere. Buddhism instead holds the offer of satisfying the intellect and leading to deliverance. The definitions furthermore show that Ouyang saw the greater problem in the current identification of Buddhism with religion (as a jiao), being well aware of the antireligious bias of the intellectual elite. While this problem was not limited to his own times, it was nevertheless very virulent at the moment of his lecture because of the anti-religious movement of the early 1920s. As for the delineation between Buddhism and philosophy (something that was more prestigious at this time - Ouyang, e.g., specifically named Russell who had just toured China and was critical about many trends in Western thinking, as a relatively positive figure), his main issue was to retain an ultimate scope for reasoning: deliverance, distinguishing Buddhism from a purely intellectual exercise. Science he included in philosophy, hinting only at the point of partial convergence between recent findings in science and age-old knowledge in Buddhism. The difference between science and Buddhism remains rather implicit: science is based only on the experimental level, whereas Buddhism has achieved these insights by meditational practice, being able also to explain causes unknown to science and its piecemeal induction approach. Still, the fact that science is subsumed under philosophy, obviously on the common ground of inductive approach, shows that it was not so important for Ouyang to attack science, or, put differently, that science had the highest prestige among non-Buddhist teachings. Since Ouyang was aware of the intellectual debates of his times, one may note that his relatively positive presentation of science also reflects a kind of reaction to Wu Zhihui, with whom Ouyang corresponded, and to Wu's "scientism," popular at that historical moment. ${ }^{9}$

In the second part of Ouyang's intended complete lecture, "Buddhism is what the present generation is in need of," he then expounds how he sees the specific relationship between Buddhism and the historical moment he lived in: Above all, he stresses the claim of Buddhist categories to absoluteness against Western ones. Therefore, Ouyang warns his compatriots against relying on Western modernity as a means to cure China's ills, especially in the form of religion (i.e., above all, Christianity) and philosophy. Only Buddhism can answer the questions of the times - as it does at all times.

Ouyang's most famous piece shows that he tended to stress the total alterity of Buddhism vis-à-vis Western thinking not only on the quantitative but also on the qualitative level with the self-confidence that Buddhism is per definition always the most actual answer to the problems of the times. Still, behind his 
seeming self-confidence there lingered the attacks on Buddhism as superstitious, anti-intellectual, unscientific etc of his age. But throughout his argumentation, starting from the absolute level of "truth," there was no possible matching of categories, and he obviously never intended to achieve such a matching. Thus, his definitions of Western categories like "religion" or "philosophy" were basically designed for apologetic use only.

In sum, Ouyang argued for the transhistorical nature of Buddhism and did not want to "modernize." Still, regarding his endeavours from without, he actually did all but propound a simple "traditional" or ahistorical Buddhism and thus - in his own special way - clearly reflected the times he lived in.

Gotelind Müller

\section{Further Reading}

Goldfuß, Gabriele. Vers un Bouddhisme du XXe Siècle. Yang Wenhui, Réformateur Laïque et Imprimeur. Paris: De Boccard, 2001.

Müller, Gotelind. Buddhismus und Moderne: Ouyang Jingwu, Taixu und das Ringen um ein Zeitgemäßes Selbstverständnis im Chinesischen Buddhismus des Frühen 20. Jahrhunderts. Stuttgart: Franz Steiner, 1993.

Pittman, Don A. Toward a Modern Chinese Buddhism: Taixu's Reforms. Honolulu: University of Hawai'i Press, 2001. 


\section{Ouyang Jingwu: Buddhism Is neither Religion nor Philosophy but What the Present Generation Is in Need of}

(China 1922)

\section{Source Text ${ }^{1}$}

What is Buddha $(f o)$, dharma $(f a)$ and buddha dharma $(f o f a)$ ? [...]

He who has attained the unsurpassable true awakening is named Buddha. The realm of the dharma is extremely broad. All the true and the illusionary, the phenomenal and the principlenatured, the conditioned and the unconditioned is comprised by it [...]. This dharma is that which is experienced by the truly awakened and that upon which the one striving for awakening bases himself; therefore, this is called the buddha dharma.

The two terms "religion" (zongjiao) and "philosophy" (zhexue) are originally Western terms which have been translated into Chinese and have by way of analogy been forced unto Buddhism. But how can they, being each of diverse meaning and of a very restricted field of content, comprise this enormously broad fofa? If one sets straight the terms and defines the words, there is no way of using either term of "religion" or "philosophy." Fofa is just fofa, fofa is just called $f \circ f$.

Further to explain: why do I say Buddhism is not religion? Answer: All religions of the world necessarily comprise four factors, but Buddhism is contrary to each. Therefore I say Buddhism is no religion. What are these four?

1. All religions venerate one or more gods and the founder of the respective religion. These gods and founders are called holy and not to be transgressed against, they are almighty and can decide about the reward and punishment of all human beings. But all human beings have to rely on them. Buddhism is not like this. When the Buddha was close to entering Nirvana, he taught his

1 "Fofa fei zongjiao fei zhexue er wei jinshi suo bixu," Ouyang dashi Yiji, 3457-3482, partial translation. The translation is based on - though not completely coextensive with - my German partial translation in Müller: Buddhismus und Moderne, 30-40, part of which appeared in English in my "Buddhism and Historicity in Early 2oth Century China: Ouyang Jingwu, Taixu and the Problem of Modernity” in Orientierungen 2/2007, 28-51, here: 30-33. 
disciples the four reliances. These are: first: rely on the dharma (teaching), not on human beings; second: rely on the meaning, not the words; third: rely on scriptures revealing the whole truth, not provisional ones; fourth: rely on wisdom, not consciousness [...]. Religion therefore cannot but curb the character of men and add to the laziness of men. In Buddhism nothing of this exists at all $[\cdots]$.

2. Every religion necessarily has its holy scriptures which are to be abided by and which cannot be discussed by the believers, on the one hand to stabilize the content of the teaching, on the other to keep the grip on people's belief. With Buddhism this is again different [...]. It is wrong to follow blindly; to be able to choose and to follow the key [teachings] is what is praised by the Buddha. This is the freedom he allows for human thinking. But to this one may object: if Buddhism is different from religion, why is there the measure of holy words? ${ }^{2}$ Answer: The measure of holy words [in Buddhism] is not like imperial edicts or directives which one may not discuss, but consists only in already proven and generally accepted words $[. .$.$] .$

3. Each religion necessarily has obligatory dogmas and precepts [...]. Again, in Buddhism this is not the case. Buddhism has only one ultimate goal. Everything else is only an expedient means [to achieve this]. This ultimate goal is the great awakening [...].

4. All people of a religious kind necessarily have a religious type of faith. What does a religious type of faith consist of? It consists of purely emotional obedience which does not permit the least of rational critique. In Buddhism this is different. The ultimate holy realization has to be achieved by personal experience. It thus is based on one's own effort [...]. There are two kinds of faith: one is the blind following of the simple-minded, the other the joyful wish of the knowledgehaving one. The former has to be discarded, the latter one is to be honored. The faith in the unsurpassable awakening and in [the fact that] others have experienced it already and that oneself and others are able to experience it by oneself, this faith is perfect, strong, and unshakable $[\ldots] .^{3}$

\footnotetext{
2 This is one part of a variant of the fivefold syllogism in Buddhist logic which testifies to the correctness of a dictum by demonstrating its congruence with the sutras.

3 "Fofa fei zongjiao fei zhexue er wei jinshi suo bixu," Ouyang dashi Yiji, 3457-346o.
} 
To say that Buddhism is no philosophy is based [on the fact that] philosophy has basically three contents, but Buddhism is contrary to each, therefore Buddhism is no philosophy. What are these three?

1. The quest of philosophy is searching for the truth, and this truth must by definition posit something that is the final substance of all things and which is the origin of everything [...]. Every day [philosophy] is searching, but can [the truth] be attained by it? If one opens a history of Western philosophy, famous philosophers - after doing away with a personal god - only superstitiously believe in an impersonal one, after doing away with monotheism they just cling to some pantheism; if they do not believe in materialism, then in idealism, if not in idealism, then in realism. A Descartes was strong at doubting, thus he did away with all things in the world as not real, but only to superstitiously believe in an ego [instead], thinking that "If I can doubt everything to be unreal, then I must be real." Now today's [Bertrand] Russell holds that this "My ego can doubt, thus the ego is real" cannot be established. Although Russell may refute materialism and idealism as not the truth, he nevertheless still clings to the phenomena as real. Thinking about it thoroughly, where is the big difference between his claim that the phenomena are real and Descartes' claim that the ego is real? In sum, all Western philosophies [...] hold on to the existence of a principle: the first thinks it lies in this, the second thinks it lies in that, others hold that both are untenable but have themselves no irrefutable teaching to convince people. To reject one tenet and set up another is nothing but augmenting the many false opinions of mankind [...]. Buddhism destructs reliance. Who does not hold onto anything, is a Buddha. Therefore Buddhism does not talk about "truth" (zhenli) $)^{4}$ but about "absolute thusness" (zhenru,tathātā) [...]. If this exists, one does not have to search for it, if it does not exist, one cannot search for it [...].

2. Philosophy discusses the question of cognition, but all topics of epistemology like the origin of cognition, its functioning, and its nature do not go beyond reasoning differentiation. With Buddhism, this is different. In the four reliances it is said: rely on wisdom, not on 
differentiating consciousness. ${ }^{5}[\ldots]$ If there is no object, there is no consciousness $[\ldots]$, therefore this is no idealism [...]. If there is no subject, there is again no consciousness [...], therefore this is no realism $[\ldots]$. If both are not there, there is again no consciousness $[\ldots]$, therefore this is no phenomenology [...]. Philosophy [separating cognition from subject and object in one way or other] is thus a teaching without results.

3. Philosophers deal with explanations of the cosmos. First there was idealism, materialism, monism, dualism; then the theory of atoms and electrons. Today science has developed the theory of relativity and has started to understand that the cosmos is nothing real. [Thus], not only has idealist monism of one-time metaphysicians no longer a reasonable basis to exist, but materialist realism is equally difficult to establish. Today's science requires equations and that all things existing in the world are only singular items, not singular material entities. Russell's followers take this up. They analyze matter and analyze mind. Analyzing matter they [find] mind, analyzing mind, they [find] matter, but thus they [take into consideration] only the phenomena, but they do not see their true essence (benti). Now, if there is no true essence, wherefrom should the phenomena arise? $[\ldots]^{6}$

What does it mean that Buddhism is what the present generation is in need of? Answer: For this question one first has to clarify a few things: For all sentient beings there are only two ways of existence: the awakened one and the aberrant one. To return from aberrance to awakening [i.e. the original state of being] there is no other way than Buddhism. Therefore, if one wants to get away from aberrance, one has to start with Buddhism. The buddha dharma is not only needed now and today, or especially by the Chinese, or mankind. Buddha expounded the necessity of awakening to [...] let all sentient beings enter the Nirvana without rest [i.e. the ultimate one of the four nirvanas as understood in the weishi theory] and have them [attain final] deliverance $[\ldots]$. The heart of man cannot be without something to be based upon (suo yong); if it does not believe in the right, then it believes in the wrong. The body of man cannot be without

\footnotetext{
$5 \quad$ Ouyang here contrasts Western epistemology with the weishi theory of eight consciousnesses and the four parts of the cognition process: subject, object, consciousness, and conscious realization of the whole process of cognition, to argue for the interdependence of consciousness, subject, and object.

$6 \quad$ Again, Ouyang introduces the weishi theory of the eight consciousnesses and how origination is explained through them. Ouyang dashi Yiji, 3461-3472.
} 
something that it fulfils (suo dong), if not the Way, then violence. Thus, what kind of evil, be it robbery, burglary, adultery, or deceit, would not be done? The confusion of today's world is only a special result, the cause of which lies in the confusion of human hearts. ${ }^{7}[\ldots]$

In his last lecture in Beiping, ${ }^{8}$ Russell told us Chinese: "You Chinese should not simply rely on Western civilization and by mere copying introduce it in the same way to China. You should realize that Western civilization has already run up into a dead end. During the last decades it has led more and more into wars. It might be that in the future the wars produced by its civilization will destroy that very civilization." These words were not spoken without reason. If we do not quickly deal [with the issue], break up all doubts of mankind, and solve all ignorance of mankind, pave away all superstition in religion and give mankind a correct faith; if we do not clarify all false opinions in philosophy and give mankind a correct understanding, let the human heart have something to rely upon, and block future disaster, then our guilt will bring never-ending calamity over our sons and grandsons. Could you, my gentlemen, endure that in your hearts?

Translated by Gotelind Müller 